\title{
Do Investors Mistake a Good Company for a Good Investment?*
}

\author{
Peter Antunovich \\ Federal Reserve Bank of New York \\ 33 Liberty Street \\ New York, NY 10045 \\ peter.antunovich@ny.frb.org \\ David S. Laster \\ Swiss Re Economic Research \\ 55 East 52nd Street \\ New York, NY 10055 \\ david_laster@swissre.com
}

August 1998

Do investors confuse the quality of a firm with its attractiveness as an investment? If so, shares of well-run companies will be bid up too high and subsequently earn negative abnormal returns. Our analysis of Fortune magazine's annual survey of “America's Most Admired Companies" for 1983-96 finds the opposite. A portfolio of the most admired decile of firms earns an abnormal return of 3.2 percent in the year after the survey is published and 8.3 percent over three years. The least admired decile of firms earns a negative abnormal return of 8.6 percent in the nine months through the end of the year, more than half of which is reversed in the first quarter of the following year. The magnitude of these abnormal returns and their persistence over five years suggest that well admired firms are not overpriced. The timing of returns to least admired firms provides evidence of window dressing.

This paper represents the views of the authors and not the views of the Federal Reserve Bank of New York or the Federal Reserve System. We thank Jean Helwege, Richard Thaler, and seminar participants at the Federal Reserve Bank of New York for helpful comments. Excellent research support by Scott Mitnick and Vhan Tran is greatfully acknowledged. 


\section{Introduction}

Are the returns to investing in highly regarded firms commensurate with their riskiness, or are they abnormally high or low? Each possibility has its proponents. Believers in market efficiency would argue that shares of well-regarded firms cannot on average realize abnormal returns. Because their stocks are closely followed, any tendency to misprice them would be thwarted by rational, opportunistic investors seeking excess returns.

Some behavioral finance theorists hypothesize that shares of highly regarded companies should earn negative abnormal returns, due either to investor irrationality or agency problems. The irrationality argument is that some investors mistakenly consider the shares of high-quality firms a prudent investment irrespective of price and bid up the shares to the point where later returns will be substandard. The agency story is that some money managers prefer investing their clients' assets in well-regarded companies so that if the shares perform poorly the clients will blame the company or the stock market, but not the advisor. If enough people are willing to sacrifice returns when investing in excellent companies, their shares will earn negative abnormal returns in equilibrium.

Another reason to suspect that shares of well regarded firms may be overvalued and shares of poorly regarded firms undervalued is that stock prices appear to overreact in some contexts. DeBondt and Thaler $(1985,1987)$ and Chopra, Lakonishok, and Ritter (1992) document that stocks that have performed especially well over a three- or five-year period tend to underperform the market over the next several years, while past laggards tend to do well. This suggests that highly regarded firms which, as we show, have experienced strong stock price appreciation over the past three years, 
should do poorly in subsequent years and that poorly regarded firms, whose stocks have done badly over the past three years, should subsequently perform well.

Shares of well-regarded firms might, however, produce positive abnormal returns if they are underappreciated by the investing public. If industry insiders and analysts learn of positive developments at high-quality firms before the general public, these shares should appreciate during the time it takes for this information to become generally known. Supporting the view that the market underreacts to publicly available information, Womack (1996) finds that stocks added to security analysts' "buy" lists earn a post-event one month abnormal return of +2.4 percent; new additions to their "sell" lists earns a post-event six-month abnormal return of -9.1 percent.

This paper examines these three competing hypotheses about the relationship between corporate reputation and equity returns using data from a survey of America's most admired firms that Fortune magazine has published annually since 1983. Forming seven equally-weighted portfolios based on reputational ranking, we find that, in each of the five years after the survey is published, the portfolio of the most-admired firms produces the highest returns; in four of the five years the portfolio of the least admired firms produces the poorest returns. Over those five years, the most-admired firms earn a cumulative return of 126 percent with less risk than the least admired firms, which earn 80 percent. Adjusting for size and book-to-market does not substantially change the results. We conclude that, despite their public availability, the assessments of corporate quality appearing in the Fortune survey contain useful information that is not immediately impounded in stock prices.

The plan of the paper is as follows. The next section describes previous work, the data employed in the analysis, and the basic methodology. Section 3 presents the summary statistics for our sample. We then examine the long-term performance of investment strategies based on 
reputation. The results, based on raw returns, market-adjusted returns, size and book-to-market adjusted returns, and industry-adjusted returns, all indicate that the decile of the most-admired firms does considerably better than the decile of the least admired firms for up to five years after the formation date. Additionally, we discuss the intra year seasonal pattern in the returns of the leastadmired firms. In Section 4, we test the statistical significance and the robustness of our results. In Section 5, we perform a return decomposition of abnormal returns to an industry component and a firm-specific component. A summary of the key results and questions for further study appear in Section 6.

\section{Background}

\subsection{Related Research}

Several recent studies suggest that the prices of individual stocks underreact over intermediate horizons of six-to-twelve months and overreact over long-term horizons of three-to-five years. Jegadeesh (1990) and Jegadeesh and Titman (1993) provide evidence that stock prices exhibit momentum over an intermediate horizon. They show that a strategy of buying stocks that have risen the most over the past six months, and selling those that have fallen the most, generally performs quite well, consistent with the hypothesis that the market takes approximately a year to fully incorporate good or bad news into the price of a stock. Similarly, researchers such as Bernard and Thomas (1990) offer evidence that stock prices take as long as four quarters to fully react to earnings surprises.

Over longer horizons, stock prices appear to overreact. As previously noted, DeBondt and Thaler (1985, 1987) and Chopra, Lakonishok, and Ritter (1992) find evidence of overreaction with 
respect to the best and worst performing stocks over three and five year horizons. Lakonishok, Shleifer, and Vishny (1994) show that "value" investing, strategies such as buying stocks with low book-to-market and earnings-to-price ratios or low growth in sales realize excess returns without additional risk. They offer several hypotheses for this superior performance: investors erroneously extrapolate past growth rates; institutions prefer owning glamour stocks because doing so seems prudent and is easy to justify to clients; and individuals equate well-run firms with good investments, regardless of price.

In this paper we test whether investors pay a premium to own shares of admired firms by measuring the returns to these shares. If investors pay too much for these firms, they should realize negative abnormal returns on their holdings. Similarly, if investors excessively bid down the shares of unadmired firms, these should subsequently earn positive abnormal returns.

Although the concepts are often used interchangeably, value stocks are not necessarily unadmired firms, just as glamour stocks are not always well-admired firms. This is because the categories "value" and "growth" are typically defined on the basis of a financial ratio, such as bookto-market or earnings-to-price. Although a low book-to-market ratio or earnings-to-price ratio should in theory correspond to a firm with ample investment opportunities, there are many reasons -accounting convention, industry membership, a bad year -- why these ratios might be high or low for a firm. Not all of these relate to the firm's reputation. When analyzing the relation between a firm's reputation and the returns to its stock, it is therefore desirable to measure reputation per se instead of equating it with a high or low financial ratio. Because the reputation of a firm is intangible and difficult to measure, however, most research on value investing makes no attempt to incorporate reputation explicitly in the analysis. 
Two papers that do consider corporate reputation provide evidence that investing in highquality firms can be a profitable strategy. Clayman (1987) finds that the returns to investing in an equally weighted portfolio of twenty-nine publicly traded firms featured in the book In Search of Excellence: Lessons From America’s Best-Run Corporations beat the S\&P 500 by 1.1 percent a year from 1981 to 1985 . Siegel (1995) shows that the long-term returns to a set of large, well-regarded growth stocks known in the early 1970s as the "nifty-fifty" justified the lofty price-earnings ratios -fourty on average -- at which they traded at their 1972 peak. This research has a few limitations. The samples of high-quality firms are small and are not updated: Siegel's firms were well regarded in 1970; Clayman's in 1982. The studies also exclude firms of low or average quality. ${ }^{1}$ And because their samples were selected partially on the basis of market-to-book and price-earnings ratios, the firms they consider are to some extent glamour stocks, as opposed to the stock of firms with excellent reputations.

The Fortune reputation survey offers several advantages over the data sets used by Clayman (1987) and Siegel (1995). The survey provides a pure measure of experts' perceptions of corporate quality. It includes hundreds of large firms running the gamut from favorites to underdogs, is updated annually, and is free of survivorship bias.

Shefrin and Statman $(1995,1998)$ show that the Fortune survey gives high ratings to firms with large market capitalizations and high market-to-book ratios, precisely the characteristics that researchers such as Fama and French (1992) associate with low stock returns. They therefore

\footnotetext{
${ }^{1}$ Clayman (1987) reports that a portfolio of "unexcellent" S\&P 500 firms with slow growth, low profitability, and low market-to-book ratios would have outperformed the index by 12.4 percent a year. The result suffers from survivorship bias, however, because one criterion for inclusion in the sample of "unexcellent" firms is that the firm is still intact and part of the S\&P 500 at the end of the sample period.
} 
hypothesize that firms rated highly in the Fortune survey underperform the market. To test this hypothesis they regress one-year equity returns on the Fortune rating on value as a long-term investment (1997, Table 10), with mixed results. The reputation measure has a positive coefficient in eight years and a negative coefficient in five years; the pooled regression has a coefficient that is negative and borderline significant.

The present analysis examines more closely the relationship between reputation and stock returns and finds it to be positive and significant, but only for firms in the extreme reputation quintiles. Considering returns over a five-year horizon enables us to confirm the persistence of these effects. We also test for robustness and seasonality and are careful to control for possible market-to-book and size effects.

\subsection{Data}

Since 1983, Fortune magazine has published an annual survey of America's Most Admired Companies (AMAC) that ranks large U.S. firms by reputation. Over time, the survey has grown in scale -- from twenty industries to fifty-five industries -- and in the attention it has received from executives, consultants, and academics. Each fall, Fortune asks thousands of executives, outside directors, and financial analysts to rate their industry's ten largest firms (sometimes fewer), as measured by sales, on a scale of zero (poor) to ten (excellent) on eight attributes. A firm's score is computed for each of the following attributes: quality of management; quality of products or services; innovation; value as a long-term investment; financial soundness; ability to attract, develop, and keep talented people; community and environmental responsibility; and use of corporate assets. Firms are then ranked by overall score, which we call the "Fortune rating," computed as an equally- weighted 
average of their scores for the eight attributes. The survey results are reported in an article that appears in the first quarter of the following year, featuring lists of the ten most and least-admired firms and a discussion of their distinguishing characteristics.

The sample period for our return analysis is from April 1983 to March 1996. We use returns data from the Center for Research in Securities Prices (CRSP) daily data tape, accounting data from Compustat (including the research file), and rankings from annual Fortune surveys of corporate reputation from 1983-95, published in the AMAC DataBook (including two years of supplementary data). Firms with shares that are not publicly traded or for which the relevant data were unavailable from Compustat were dropped from the sample.

A key advantage of our sample is that it suffers little from survivorship bias. This bias results when firms are added retroactively to a data set, based on their subsequent performance. For example, Lakonishok, Shleifer, and Vishny (1994) note that Compustat's more than doubling of its universe of firms in 1978 might create problems because the smaller firms that were added to the dataset were generally the ones that had performed well in the past. Thus, as one looks at firms with progressively smaller market capitalizations, the population increasingly consists of firms with solid five-year performance records. This might help explain why studies using these data find that stocks with small market capitalizations have high average returns.

Our dataset suffers very little, if at all, from this problem. The sample is not backfilled -- the identity of the firms covered in the survey are announced each year and are not changed retroactively. Moreover, although firms do drop out of the sample, usually because of mergers, these deletions are also publicly known as they occur. Any survivorship bias that does exist would be due to the 
backfilling of accounting data on Compustat. This should not be too much of a problem, however, because our sample is post-1980 and consists predominately of large firms.

\subsection{Methodology}

Each year from 1983 to 1995 we take the firms included in the Fortune survey and eliminate those for which CRSP data was not available. The remaining firms are then sorted into five quintiles based on their Fortune ratings. Quintile Q1 comprises of the firms that are most admired while, quintile Q5 contains the least-admired firms. These two extreme quintiles are further divided in half, with Q1A representing the decile of firms with the highest Fortune ratings and Q5B representing the decile of firms with the lowest ratings. Last, we eliminate from each portfolio the firms without the relevant accounting data available on Compustat. This procedure yields seven portfolios, which we call "reputation" portfolios. ${ }^{2}$

Using these groupings, we form our equally weighted reputation portfolios of stocks at the start of each April after the publication. The exact publication date of the Fortune survey results has drifted over the years from January to March, but has never been later than March 6. Our forming of portfolios on April 1 thus allows ample time for the survey results to become publicly available. To track the portfolio performance, we compute a return to a buy-and-hold strategy for periods from one to five years. Beside the raw returns we compute the returns adjusted for (i) market, (ii) size and

\footnotetext{
2 There are two rationales underlying our procedure. The first is to test a simple trading strategy, the implementation of which does not require the knowledge of whether the firm's accounting data is available on Compustat. We therefore sort the firms into reputation portfolios without checking whether they are covered by Compustat. The second rationale is to maintain a consistent sample of firms across all our return computations. Because the computation of size and book-to-market adjusted return requires accounting data from Compustat, we subsequently eliminate all the firms for which this data is not available. Alternative classification procedures yielded almost identical results.
} 
book-to-market, and (iii) industry by using appropriate reference portfolios. The presented summary statistics are based on pooled returns across the period 1983-95.

We use a modified buy-and-hold strategy, where the reputation portfolios and reference portfolios are rebalanced into equally weighted portfolios at the start of each April. Following this approach, we compute a five-year return by cumulating five one-year, buy-and-hold returns. The purpose of rebalancing is two-fold. First, if a firm is delisted during a given annual holding period, it is dropped from the portfolio at the start of next April. Second, annual rebalancing represents a compromise between monthly rebalancing and a pure buy-and-hold strategy. As discussed by Barber, Lyon, and Tsai (1998), the abnormal returns based on a pure buy-and-hold strategy precisely measures the actual investor experience, however, the resulting test statistics suffer from the skewness bias. In contrast, the use of abnormal returns based on monthly rebalancing improves the specification of test statistics, but is inferior in describing the actual investor experience. We therefore use annual rebalancing as a compromise between the two extremes.

To avoid inducing a survivorship bias, we replace the missing CRSP returns of the delisted firms in a consistent way for the sample and the reference firms. In the case of raw and marketadjusted returns, we splice in the return on a value weighted market index; if a firm is delisted because of a bankruptcy, this procedure automatically sets the firm's annual return equal to zero. This procedure eliminates the survivorship bias that may occur because the least-admired firms are delisted more often than the most-admired firms. In the case of size/book-to-market and industry adjusted returns, we simply splice in a zero return until the end of the annual holding period. Because we consistently treat the delisted sample and reference firms, we should not induce any survivorship bias. 
When we calculate the summary statistics for the four return measures, we always use the maximum of available return data. For example, because the CRSP return data is available only through April 1996, we cannot compute a full set of five annual returns for the period 1992-96. However, we include return data for these survey years to the extent possible. The details of the design characteristics, specific to each of the four return measures, are as follows.

Raw and market-adjusted returns. Raw and market-adjusted returns are based on annual buyand-hold returns. If a certain sample firm drops out of the CRSP database in a given year, we reallocate the proceeds, based on the last day's returns reported on CRSP, to the CRSP valueweighted index for the remainder of the year. As mentioned earlier, the delisted firms are subsequently dropped from the portfolio at the start of next April.

For the case of market-adjusted returns, we measure the market performance using the CRSP value-weighted market return. A one year market-adjusted return is then defined as the one-year buyand-hold return on the sample firm minus the one-year return on the CRSP value weighted index.

Returns adjusted for size and book-to-market. Fama and French (1996) and other researchers have shown that firm size and book-to-market ratio are important factors in explaining cross-sectional returns. Because the firms with high Fortune ranking tend to be large and have low book-to-market ratios, it is possible that the differences in returns across our portfolios can be explained by these two factors.

To assure that our results are not merely artifacts of size and book-to-market, we examine firm returns adjusted for these two factors using the approach of Barber, Lyon, and Tsai (1998). We compare the returns of each sample firm with the returns of a reference portfolio matched on size and book-to-market ratio. We measure firm size based on the market value of equity at the start of April. 
The book-to-market ratio is calculated using the book value of equity at the start of October in year t-1 (or the first earlier available date), divided by the market value of equity at the start of October in year t-1. As in Fama and French (1996), this procedure guarantees that the data used to compute the ratio is at least six months old.

To compute the abnormal returns, we construct seventy size/book-to-market reference portfolios similar to Barber, Lyon, and Tsai (1998). Each year, we first split the universe of NYSE stocks into deciles based on their market value as of the start of April. Second, based on their market value of equity, we place AMEX and Nasdaq firms into the appropriate deciles. Third, the firms in the smallest size decile are then further partitioned into quintiles, yielding fourteen size portfolios. Finally, the firms within each of the size portfolios are split into quintiles based on their book-tomarket ratio.

Each sample firm is then matched with the appropriate reference portfolio based on the value of equity and book-to-market ratio. We define the buy-and-hold abnormal return in a time interval between $\mathrm{T}_{1}$ and $\mathrm{T}_{2}$ as:

$$
\mathrm{BHAR}_{\mathrm{i}, \mathrm{T}_{1}, \mathrm{~T}_{2}} \underset{\mathrm{T}_{1}}{\min \left[\mathrm{T}_{2} \text {, delist }\right]}\left[\begin{array}{ll}
1 & \mathrm{R}_{\mathrm{i},}
\end{array}\right] \underset{\mathrm{T}_{1}}{\min \left[\mathrm{T}_{2}, \text { delist }\right]}\left[\begin{array}{lll}
1 & \mathrm{R}_{\mathrm{c},}
\end{array}\right],
$$

where $\mathrm{R}_{\mathrm{c}, \mathrm{t}}$ is the daily return on the sample firm and $\mathrm{R}_{\mathrm{c}, \mathrm{t}}$ is the daily return on the reference portfolio. The end of the cumulation period is determined by the last day of CSRP-listed trading of the sample firm, or the end of the window of interest, whichever is earlier.

The average BHAR for the annual holding period starting at the start of April in year $\mathrm{t}$, is calculated as: 


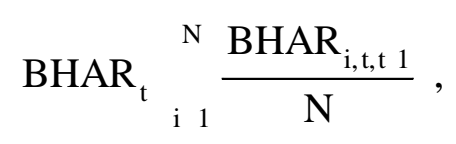

where $\mathrm{N}$ is the number of remaining sample firms in the portfolio as of the beginning of April in year t. We use the average BHAR to compare the returns of sample firms with those of their reference portfolios for holding periods from one to five years after the publication.

Industry-adjusted returns. In computing the industry-adjusted returns, we focus on the question of whether returns associated with reputation represent firm-specific or industry effects. The industries in the survey are defined based on Fortune's classification instead of SIC classification. Moreover, Fortune survey is restricted to ten (or less) largest firms (in terms of sales) in each industry. Because the Fortune reputation score of the firms excluded from the survey is unobservable, a natural way to compute an industry benchmark is to restrict attention only to the industry peers covered by the Fortune survey. Our definition of industries therefore simply coincides with the Fortune's industry groupings. Most so-defined industries consist of ten firms included in the survey. However, after matching the survey data with CRSP and Compustat, some industries contain only a few firms. Because in such cases the calculation of industry-adjusted returns would contain little useful information, we eliminate all the industries with less than five firms in a given year. The industry-adjusted return for the remaining firms is computed as a difference between a buy-and-hold return on the firm i and a buy-and-hold return on an equally weighted industry portfolio, excluding firm i. The industry portfolios are formed at the start of each April after the survey, held for five years, and are rebalanced annually into equally weighted portfolios at the start of each April. 


\section{Empirical Results}

\subsection{Descriptive Statistics}

Before reviewing the returns to investing in firms with good, bad, and indifferent reputations, we first examine their basic characteristics. McLaughlin, Ruback, and Tehranian (1996) find that firms rated highly in the Fortune survey tend to be highly profitable, to grow rapidly, and to acquire other firms, but they do not tend to be acquired. The ratings contain useful information not captured by Tobin's q, the ratio of a firm's market value to the replacement cost of its assets. Our analysis, summarized in Table I, shows that well-regarded firms have large market capitalizations, high stock prices, low book-to-market ratios, and consistent profitability. The unadmired firms have the opposite characteristics, high betas and standard deviations, and low past returns.

Market capitalization and book-to-market. Consistent with Shefrin and Statman (1995, 1998), reputation is closely related to size and book-to-market (B/M) ratio. Median market capitalization increases monotonically with reputation. Expressed in 1992 dollars, the median firm in the most-admired decile Q1A has a market capitalization of $\$ 11.5$ billion; the median firm in the least-admired decile has a market cap of $\$ 837$ million, less than a tenth as much. Additional calculations not reported here show that 86 percent of Q1A firms are in the largest NYSE market cap decile as opposed to just 11 percent of Q5B firms, whose median market cap decile is the fourth. ${ }^{3}$ Admired firms trade at low $\mathrm{B} / \mathrm{M}$ ratios, reflecting their perceived opportunities. The median firm in

\footnotetext{
${ }^{3}$ Because the Fortune survey includes only the ten firms with highest sales in each industry, our sample consists mainly of large cap stocks. Based on NYSE break points, the percentages of the overall sample in the three largest market cap deciles are, respectively, 45, 24, and 12; just seven percent of the firms are in the bottom five NYSE size deciles.
} 
the most-admired decile has a $\mathrm{B} / \mathrm{M}$ of .34 , less than a third of the 1.11 ratio for the least-admired decile.

Risk measures. Taken individually, shares of the most-admired firms have the safest return performance: beta and standard deviation are each a declining function of reputation. Firms in the least-admired decile of firms are especially risky, with betas 0.25 higher and standard deviations 50 percent more than middle quintile firms. This volatility may be related to the smaller market capitalizations of the least-admired firms.

Earnings stability. Consistent profitability inspires admiration. Reputation is highly correlated with the proportion of quarters in which firms lost money in the three years prior to the survey. The most-admired firms reported losses just 2 percent of time, while the least-admired firms lost money 38 percent of the time.

Lagged returns. Firms with excellent reputations can be expected to have strong historical returns for two reasons. As noted, admired companies have had good operating results, which should help raise their stock prices. Also, a rising stock price might itself enhance a firm's reputation.

Returns for the year prior to the survey are positively related to reputation. The most-admired decile earned returns nearly twenty percentage points higher than the least-admired decile, whose firms had considerably lower returns than the rest of the sample. The positive relation between reputation and lagged stock returns is more pronounced over a three-year horizon. The least-admired firms had a median three-year return of just 12 percent as opposed to 100 percent for the mostadmired. This relation was nearly monotonic.

Returns to the stocks over the October-March period, when the survey results were collected and tabulated, varied little across portfolios. The absence of a relationship between reputation and 
stock returns during the six months prior to portfolio formation means that the high returns to admired firms and low returns to unadmired firms in our sample is not solely a reflection of the momentum in stock returns documented by Jegadeesh and Titman (1993).

Persistence of reputation. Reputation exhibited multiyear persistence. Of the firms rated among the most-admired decile of firms in a given year, the percentage remaining in the top decile after one, three, and five years was 75, 62, and 52, respectively; the corresponding percentages for the bottom decile were 74,53 , and 32 . By contrast, not a single top decile firm migrated to the bottom decile after five years, or vice versa.

Share price and NYSE listing. Median share price, which varies monotonically with reputation, is $\$ 52$ for the most-admired firms and $\$ 17$ for the least-admired. The proportion of firms listed on the New York Stock Exchange is about 95 percent for all but the least-admired group, whose proportion is 88 percent.

\subsection{Annual Returns}

Our main results concern stock returns over the five years after the Fortune survey is published. Of the seven reputation portfolios, the most-admired firms has the highest returns and the least-admired firms has the lowest returns in each of the three years after the survey is published

(Table II, Panel A). Five-year cumulative returns are 126 percent for the most-admired portfolio, 80 percent for the least-admired portfolio, and between 102 and 107 percent for the other portfolios. Relative to the CRSP value-weighted index, the most-admired firms had annual excess returns of 4 percent in the first three years and 3 percent in the next two years (Table II, Panel B). The least- 
admired firms had market-adjusted returns that were negative in four of five years and averaged -1.6 percent per year.

Adjusting returns for size and book-to-market leaves the average gap in returns between the least and most-admired firms virtually unaffected but increases the first-year underperformance of least-admired firms to 5 percent (Table II, Panel C). Over a five-year horizon, the five intermediate portfolios have average abnormal returns very close to zero -- from 0.1 percent to 0.3 percent a year. The most-admired firms earn abnormal returns of 2 percent a year; the least-admired firms earn abnormal returns of -3 percent a year.

Note that in both Panel $\mathrm{B}$ and $\mathrm{C}$, the abnormal returns are the strongest for the extreme reputation deciles. This pattern is especially pronounced in the case of the returns adjusted for size and book-to-market effects, which suggests that our reference portfolios capture the cross-sectional variation in returns well for all but the two extreme decile portfolios. We believe that the disproportionate results in the tails can be explained by the presence of noise in the reputation ratings given by each analyst or executive. Focusing on the extreme deciles eliminates all but those firms where there is near-unanimity about quality, whether good or bad.

Industry-adjusted returns follow the same general pattern: the most-admired firms earn the highest returns while the least-admired firms bring up the rear (Table II, Panel D). A comparison of average returns to the two extreme portfolios stated in Panels C and D suggests that their industryadjusted returns have the same sign but are only about 40 percent as high as their size and book-tomarket adjusted returns. Thus, slightly more than half of the abnormal returns to investing in the most-admired firms -- or selling short shares of the least-admired firms -- derives from the strategy's 
ability to identify industries whose prospects are good or bad; the remaining outperformance is due to choosing the right firms within those industries.

\subsection{Pattern of Monthly Returns}

Monthly returns provide a clearer view of how the most- and least-admired firms perform. One characteristic of these returns, which are adjusted for size and book-to-market ratio, is their asymmetry. Over the five-year event window, least-admired firms earn negative abnormal returns more than twice the magnitude of the positive abnormal returns to the most-admired firms (Figure 1). Returns to the least-admired firms follow a trend that persists over the entire five-year event window; returns to the most-admired firms peak in the 33rd month and are stable thereafter.

The returns to the two portfolios also differ with respect to seasonality. Cumulative abnormal returns to the most-admired portfolio drift consistently upward over the first three years. Abnormal returns to the least-admired portfolio are sharply negative for the nine months after portfolio formation (April-December) and then rebound over the next three months. This pattern of nine-month decline and three-month rebound repeats itself in each of the subsequent four years, although the first year's decline is the sharpest.

The cumulative return performance to the strategy of buying shares of the most-admired companies and selling short the stocks of the least-admired companies contrasts sharply with the findings of DeBondt and Thaler's (1985, Figure 3) for a five-year horizon. DeBondt and Thaler found that buying shares in firms whose stock prices had fallen most sharply over the prior several years and selling short shares in firms whose share prices had risen the most provided significant excess returns over the next five years, evidence that investors had overreacted. Our analysis shows that admired 
companies provide positive excess returns while the least-admired companies do just the opposite, suggesting that investors underreact to corporate quality.

Table III focuses further on the seasonality of returns in the first year after portfolio formation. Differences in monthly raw returns to the most and least-admired firms (column 1) follow a consistent seasonal pattern: least-admired firms outperform in January through March; mostadmired firms outperform in April through December, except for July. Large and significant difference in returns between the least and most firms occurred in January (-6.2 percent), October (5.1 percent), May (2.4 percent), and December (2.4 percent). The proportion of years in which the difference in returns was positive follows the same pattern (column 2).

To pinpoint the source of this seasonality, we next look at size and book-to-market adjusted returns to the two extreme portfolios. Adjusted returns to the most-admired firms are remarkably stable throughout the year: no month has average returns with absolute value of more than 0.75 percent and the proportion of years with positive adjusted returns never significantly deviates from a half (columns 3 and 4).

Adjusted returns to the least-admired firms have a more pronounced seasonal pattern that mirrors the seasonality of the gap in returns between the most and least-admired. Least-admired firms perform extremely well in the first three months of the year, especially January, in which their abnormal return is positive 92 percent of the time and averages 3.9 percent. Because our return measure is adjusted for size, these results are somewhat stronger than the well-known January effect for small firms and seem to reflect a market reaction to firms with poor reputation that is stronger and more fundamental than investors buying and selling small cap stocks. Abnormal returns are 
-4 percent for April through June, 0 for July and August, and -6 percent for September through December. In December adjusted returns are negative 85 percent of the time.

A simple explanation for this seasonality in returns is window dressing. Portfolio managers are evaluated based on past performance, but this criterion alone is not enough because returns are subject to noise. As Lakonishok, Shleifer, and Vishny (1994) note, people evaluating a manager's skill supplement their statistical analyses by examining his or her portfolio holdings. Because these holdings are generally reported at year-end and (less often) at midyear, managers have a strong incentive to hold highly regarded stocks and to avoid holding poorly regarded companies at those times. Because the least-admired firms have one-thirteenth the market cap of the most-admired firms, this behavior should have a far more pronounced effect on their share prices. Consistent with this story, the least-admired firms experience poor returns in October through December as managers pare their holdings of these stocks. After reporting their holdings as of year-end, they reenter these stocks in January, causing their prices to rise sharply. This pattern is repeated, albeit on a reduced scale, in April through June, when the stocks decline prior to the midyear reporting of holdings, and in July, when they rise as some investors once again enter the stocks.

Quarterly market-adjusted returns to the seven portfolios confirm this pattern (Table III, Panel B). Significant quarterly returns are concentrated in the fourth quarter, in which the most-admired firms do well ( +2.4 percent $)$ and the least-admired firms fare poorly (-6.7 percent), and in the first quarter, in which the three least-admired portfolios all earn market-beating returns. 


\section{Statistical and Robustness Tests}

The presented results indicate that the decile of the most-admired firms on average outperforms the decile of the least-admired firms for up to five years after the portfolio formation date. Although the observed return differences are economically significant, so far we have not estimated their statistical significance. Related to this question, we also did not examine whether the most-admired firms may be inherently riskier, as compared with the least-admired firms, to the extent that the difference in risk could explain the difference in observed returns. In this section we address these question in three ways. First, we examine the statistical significance of our results by accounting for the specifics of our dataset and our research design. Second, we examine how robust the return premium of the most-admired firms is relative to the least-admired firms in the best and the worst periods in terms of the overall stock market performance. Finally, we examine the stability of the long-term return premium across different years.

To begin, we examine the statistical significance of our results. When computing the variance of a long-term return on a portfolio of firms, some studies do not account for the cross-sectional correlation between the returns of individual firms in the portfolio. For example, the Barber, Lyon, and Tsai (1998) procedure of calculating the test statistics is based on the buy-and-hold abnormal returns of individual firms. When the cross-sectional abnormal returns on individual firms are positively correlated, the estimated variance of a portfolio return is negatively biased, which in turn leads to inflated test statistics. This may occur even though the individual occurrences of the event studied may be scattered in calendar time. The longer the holding period for which the abnormal returns are calculated, the more likely it is that there will be a significant overlap in the returns of individual firms. 
To avoid this problem, Barber, Lyon, and Tsai (1998) propose an alternative method of aligning the returns in calendar time instead of event time. The advantage of this approach is that the portfolio variance can be estimated using the time series variation of portfolio returns instead of the average variance of the individual firms. Such a variance estimate correctly accounts for the potential cross-sectional correlations in individual firm returns without a need to explicitly estimate the variance-covariance matrix. This is the approach we use in our study.

In our case, the calculation of returns in calendar time is a natural choice, since the Fortune survey results are published simultaneously for all firms. The portfolio variance is thus estimated using the time series variation of annual portfolio returns across all formation periods. However, for holding periods longer than a year, we face an additional difficulty of nonindependent returns. As discussed earlier, a firm that is in the portfolio of most-admired firms in year $t$ is likely to remain in the same portfolio in year $\mathrm{t}+1$. Suppose that a given firm joins the portfolio of most-admired firms in year $\mathrm{t}$ and remains there for $\mathrm{n}$ years. When computing an $\mathrm{n}$-year return on the portfolios of most-admired firms formed in years $t$ and $t+1$, the firm's inclusion in both portfolios will contribute to the portfolios' returns being positively correlated. Moreover, this overlap does not occur only for portfolios formed in two consecutive years but remains in effect for all portfolios formed up to n-1 years after year t. To correct for this correlation, we use the Newey-West procedure, where we allow the n-year returns to be correlated up to a lag $\mathrm{n}-1 .^{4}$

\footnotetext{
${ }^{4}$ For the Newey-West procedure to be appropriate for our case, the correlations across portfolios formed in different years must (i) remain stable over time and (ii) decrease in lag. The first condition is satisfied because the probability of a firm to remain in the decile of the most or least-admired firms turns out to be stable over time. The second condition is satisfied by the construction of the holding returns: the more distant the two portfolios' formation periods, the smaller is the number of overlapping firms, and the smaller is the induced correlation.
} 
In the computation of test statistics, we focus on two investment strategies (i) buying a portfolio of most-admired firms and shorting the portfolio of least-admired firms, and (ii) buying a portfolio of most or least-admired firms and shorting the corresponding reference portfolios, which match the sample firms on size and book-to-market. Under both strategies, portfolios are formed at the start of each April after the survey publication, and held for periods ranging from nine months to five years. The results are presented in Table IV. The second column of Table IV reports the difference in five-year raw returns between the decile portfolios of most and least-admired firms. Based on the CRSP data available to us, the last portfolios that we could consider were the ones formed in 1991. The average five-year return difference is 53.7 percent, significant at the 6 percent level.

The rest of the columns in Table IV present the returns difference between the portfolios of most and least-admired firms and the corresponding size and book-to-market reference portfolios. For a nine-month holding period, the returns on the most-admired firms are +2 percent, insignificant at the conventional level, whereas the returns on the least-admired firms are -10 percent, significant at the 1 percent level. For a one-year holding period, the average returns on the decile of the mostand least-admired firms are +3 percent, and -5 percent, both insignificant at the conventional levels. This indicates a strong reversal in the returns of the least-admired firms in the first calendar quarter, similar to a well-documented seasonality in the returns of small firms. ${ }^{5}$ However, we obtain the strongest results at a five-year investment horizon: the average abnormal returns on most-admired and least-admired firms are +9.4 percent and -22.8 percent, significant at the 1 percent and 5 percent respectively.

$5 \quad$ See for example Keim (1989). 
Secondly, we address the question whether the observed return difference between the most and least-admired firms is a reflection of a risk premium. To this end, we follow a nonparametric approach advocated by Lakonishok, Shleifer, and Vishny (1994) by examining the behavior of the return difference between the most and least-admired firms in the good and bad months, as defined by market performance. The approach derives from the premise that for the return difference to be a reflection of a risk premia, it has to be associated with payoff relevant factors such as the return on the market.

We first rank all the months from April 1983 to March 1995 based on the return on an equally weighted CRSP market index and then split them into four groups: the best ten months, the worst ten months, ninety-five positive months other than the best ten, and fourty-one negative months other than the ten worst. Second, we compute the returns on the reputation portfolios across the four groups of months. The results are presented in Table V.

The results indicate that the most-admired firms on average outperformed the least-admired firms both in the ten best (by 1.8 percent a months) and in the ten worst months (by 0.7 percent a month). Additionally, the most-admired firms on average outperformed the least-admired firms in the fourty-one negative months (by 0.9 percent) in contrast to the ninety-five positive months, where they fell marginally behind (by 0.01 percent). These results suggest that the most-admired firms outperform the least-admired firms when good returns count the most, that is, in the times of market downturns. This may be a reflection of a "flight to quality," an often used phrase in the times of market downturns. Interestingly, the most-admired firms also outperformed the least-admired firms during the best ten months, thus offering a high upside potential with a low downside risk. 
These results suggest that superior returns of the most-admired firms are not due to a higher systematic risk. Our failure to relate the return difference between the most and the least-admired firms to market performance suggests that for the return difference to be a reflection of a risk premium, it has to be associated with an unidentified factor that is of a lesser payoff relevance.

Last, we examine whether the returns on the most and the least-admired firms, adjusted for size and book-to-market effects, are stable over time. Figure 2 presents the five-year buy-and-hold abnormal returns (BHAR), adjusted for size and book-to-market effects, for portfolios formed in each of the years 1983-91. The results indicate that the most-admired firms have outperformed their reference portfolios in seven out of the eight years, and that the least-admired firms underperformed their reference portfolios in seven out of the eight years. The only year with a poor showing for the most-admired firms was the portfolio formed in 1983, and the only good year for the least-admired firms was the portfolio formed in 1991. Results in Figure 2 thus suggest that the most (least) admired firms outperformed (underperformed) their size and book-to-market reference portfolios with a surprising consistency.

\section{Industry Effects}

The final question we address is the extent to which respondents to the Fortune survey differentiate between more and less promising industries for investment. To examine this question, we measure five-year returns to the most and least-admired deciles of firms as before with one added dimension. In addition to computing returns to the reputation portfolios, we also measure returns to corresponding benchmark portfolios, constructed by substituting for each firm an equally weighted index of the other firms in its industry (as described in Section 2.3). 
The results, in Table VI, demonstrate two phenomena. First, the industry benchmark associated with the most-admired decile of firms consistently outperforms the benchmark for leastadmired firms by an average margin of nearly 3 percent a year. In other words, firms that rank high in the Fortune survey are in industries that produce higher returns than are firms that rank low. A second phenomenon to note is performance relative to industry benchmark. In each of the five years in the post-survey period, the firms selected as the most-admired outperform their industry peers, by a margin of 0.5 to 1.0 percent. The least-admired decile underperformed its benchmark in four of five years an average of 1.4 percent.

\section{Conclusion and Implication}

We find that the most-admired decile of firms, as ranked by the Fortune's survey of America's Most Admired Companies in years 1982 to 1995, significantly outperforms the least-admired decile. In the five years after the survey was published the most-admired decile earned an average annual return of 17.7 percent versus 12.5 percent for the least-admired decile. This result is surprising because the most-admired firms tend to be larger and have a higher book-to-market ratio, two characteristics that Fama and French (1992) find to be associated with lower returns. The return premium on most-admired firms, adjusted for size and book-to market effects, is stable over the sample period, which suggests that they are not merely an artifact of the time period examined. The superior returns of the most-admired firms cannot, moreover, be attributed to higher systematic risk as confirmed by our non-parametric tests.

Our findings differ from those of DeBondt and Thaler $(1985,1987)$, who find that buying past losers and selling past winners produces positive abnormal returns. The most-admired firms in our 
sample typically have a superior record of past returns as compared with the least-admired firms, yet they continue to outperform the least-admired firms for up to five years after the survey. Finally, the return momentum phenomenon documented in Jegadeesh and Titman (1990) cannot explain our results because the most and least-admired firms have almost identical 6-month lagged returns at portfolio formation.

Our findings therefore add to the list of anomalies in which investors underreact to publicly available information. In form and spirit, our results resemble the earnings announcement anomaly (Bernard and Thomas (1990)), whereby an earnings surprise produces an incomplete announcement reaction followed by post- announcement drift. Contrary to the earnings anomaly, in which the trend reverses itself after four quarters, we find no reversals for up to five years after the Fortune survey is published. Womack (1996) finds an underreaction similar to ours for analyst recommendations. But this investors' underreaction seems to be relatively short lived, lasting under a year.

Our research raises some interesting questions. How can reputation, a sluggish and publicly known attribute, predict future long-term returns? Moreover, why do the least-admired firms, despite being relatively large, exhibit a pronounced seasonality in their returns, akin to a small-firm January effect? A potentially fruitful venue for resolving these puzzles may lie in linking the incentive structure of mutual fund managers to corporate reputation. First, Brown, Harlow, and Starks (1996) find that fund managers' behavior is consistent with a tournament-like payoff, where the top performers are rewarded disproportionately in comparison to managers whose performance is average. Second, Lakonishok, Shleifer, and Vishny (1994) argue that fund managers are evaluated not only on the basis of their return performance, but also based on their holdings. This suggests a motive for window dressing. 
If fund managers are indeed driven to gamble to perform well relative to their peers, this may increase their appetite for riskier stocks. At the same time, the fund managers may be reluctant to gamble with small, no-name firms. Instead, they may prefer relatively well-known, larger firms that have fallen out of favor with industry insiders and investors. Our decile of the least-admired firms fits this profile well. These firms, by survey design, are among the ten largest in their industry and are therefore relatively well known. If investments in such firms sour, the outcome can be blamed on the firms instead on the fund manager. Yet these firms, whose stocks are more volatile, offer greater upside potential than the decile of the most-admired firms.

Fund managers may be especially inclined to add these stocks to their holdings at the beginning of a calendar year, when the annual race begins, to unwind their holdings in the second quarter for midyear window dressing purposes, and to repeat similar actions in the third and fourth quarter. Such behavior might help explain why the decile of the least-admired firms performs strikingly well in the first calendar quarter, mediocre in the third quarter, but very poorly in the second and fourth quarters. However, this story does not explain why the admired firms outperform the unadmired firms over horizons longer than one year. For this to hold, the speculative motive would have to outweigh the window-dressing motive for periods of several years. Further investigation of these hypotheses is left to future research. 


\section{References}

Barber, Bred M., John D. Lyon, and Chih-Ling Tsai 1996, Improved methods for tests of long-run abnormal returns, Journal of Finance, forthcoming.

Bernard, Victor L, and Jacob K. Thomas, 1990, Evidence that stock prices do not fully reflect the implications of current earnings for future earnings, Journal of Accounting and Economics 13, 305-40.

Brown, Keith C., W.V. Harlow, and Laura Starks, 1996, Of tournaments and temptations: An analysis of managerial incentives in the mutual fund industry, Journal of Finance 51, 85-110.

Chopra, N., Josef Lakonishok, and Jay Ritter, 1992, Measuring abnormal performance: Do stocks overreact?, Journal of Financial Economics 31, 235-268.

Clayman, Michelle, 1994, Excellence revisited, Financial Analyst Journal, 61-65.

DeBondt, Werner F. M., and Thaler, Richard H., 1985, Does the stock market overreact?, Journal of Finance 40, 793-805.

DeBondt, Werner F. M., and Thaler, Richard H., 1987, Further evidence on investor overreaction and stock market seasonality, Journal of Finance 42, 557-581.

Fama, Eugene F., 1997, Market Efficiency, Long-Term Returns, and Behavioral Finance, Center for Research in Security Prices, University of Chicago, working paper.

Fama, Eugene F. and Kenneth R. French, 1992, The cross-section of expected stock returns, Journal of Finance 47, 427-465.

Jegadeesh, Narasimhan, 1990, Evidence of predictable behavior of security returns, Journal of Finance 45, 881-898.

Jegadeesh, Narasimhan and Sheridan Titman, 1993, Returns to buying winners and selling losers: Implications for stock market efficiency, Journal of Finance 48, 65-91.

Keim, Donald B., 1983, Size related anomalies and stock return seasonality: Further empirical evidence, Journal of Financial Economics 12, 13-32.

Kothari, S.P., and Jerold B. Warner, 1997, Measuring long-horizon security price performance, Journal of Financial Economics 43, 301-339.

Lakonishok, Josef, Andrei Shleifer, and Robert W. Vishny, 1994, Contrarian investment, extrapolation, and risk, Journal of Finance 49, 1541-1578.

McLaughlin, Robyn M., Richard S. Ruback, Hassan Tehranian, 1996, Does corporate quality matter?, Suffolk University, working paper.

Siegel, Jeremy J., 1995, The nifty-fifty revisited: do growth stocks ultimately justify their price?, Journal of Portfolio Management, 8-20.

Shefrin, Hersh and Meir Statman, 1995, Making sense of Beta, Size, and Book-to-market, Journal of Portfolio Management 21, 26-34.

Shefrin, H. and M. Statman, 1998, Comparing Expectations about Stock Returns to Realized Returns, Santa Clara University, working paper. 
Womack, Kent L., 1996, Do brokerage analysts' recommendations have investment value?, Journal of Finance 51, 137-67. 


\section{Table I}

\section{Properties of Reputation Portfolios: April 1983 to March 1996}

At the start of April of each year t, 7 portfolios are formed on the basis of the overall reputation ranking in the annual Fortune magazine survey of America's Most Admired Companies (AMAC). Portfolios 2-4 cover reputation quintiles. The top and bottom 2 portfolios (Q1A, Q1B, Q5A, and Q5B) divide the extreme quintiles in half.

Reputation is the time-series average of annual average reputation scores of firms in each portfolio. Market equity is measured in April of year $t$ and expressed in billions of 1992 dollars. B/M, the book-to-market ratio, uses market equity as of October in year $\mathrm{t}-1$ and book equity as of the same point in time or as of the first prior available date. Market equity and $\mathrm{B} / \mathrm{M}$ are the time series of the annual median values of firms in each portfolio.

6-month survey period returns are from October of year t-1 through March of year t. Lagged 1-year return is for the twelve months prior to October of year t-1; lagged 3-year return is for the 36 months prior to October of t-1. All return measures are in percent and are the time series average of the average value for stocks in each portfolio.

$\mathrm{NI}<0$ represents a fraction of the quarters with a negative net income over the 3 years prior to October of year $\mathrm{t}-1$.

Beta is computed relative to the CRSP equally weighted index based on three years of daily returns for the period through March of year t. Standard deviation, based on the same three years of daily data, is annualized and expressed in percent. Share price is the mean of the yearly median closing prices on April 1. NYSE is the percentage of the firms that are listed on NYSE.

Firms is the average number of stocks in each portfolio each year.

\begin{tabular}{lccccccc}
\hline & Most-Admired & & & & & \multicolumn{2}{c}{ Least-Admired } \\
& Q1A & Q1B & Q2 & Q3 & Q4 & Q5A & Q5B \\
\hline Reputation & 7.79 & 7.21 & 6.79 & 6.33 & 5.88 & 5.34 & 4.48 \\
Market equity & 13.53 & 6.65 & 4.33 & 3.06 & 2.40 & 1.96 & 1.04 \\
B/M & 0.344 & 0.501 & 0.570 & 0.638 & 0.767 & 0.989 & 1.113 \\
6-month survey & 0.139 & 0.125 & 0.114 & 0.121 & 0.144 & 0.151 & 0.136 \\
period returns & & & & & & & \\
Lagged 1-year & 0.249 & 0.214 & 0.199 & 0.181 & 0.205 & 0.165 & 0.053 \\
return & & & & & & & \\
Lagged 3-year & 1.005 & 0.918 & 0.794 & 0.659 & 0.674 & 0.432 & 0.120 \\
return & & & & & & & \\
NI 0 & 0.023 & 0.041 & 0.057 & 0.081 & 0.132 & 0.220 & 0.376 \\
Beta & 1.070 & 1.140 & 1.120 & 1.110 & 1.150 & 1.250 & 1.360 \\
Standard deviation & 0.281 & 0.291 & 0.295 & 0.299 & 0.316 & 0.345 & 0.462 \\
Share Price & 52.0 & 48.6 & 44.5 & 39.7 & 34.4 & 28.8 & 16.9 \\
NYSE & 94.3 & 95.3 & 96.7 & 93.7 & 95.6 & 97.5 & 88.4 \\
Firms & 24.2 & 24.8 & 51.4 & 48.7 & 44.1 & 21.2 & 19.2 \\
\hline
\end{tabular}




\section{Table II}

\section{Returns to Reputation Portfolios: April 1983 to March 1996}

At the start of each April between 1983 and 1995, we form seven portfolios based on the overall reputation score in the latest annual Fortune magazine survey of America's Most Admired Companies (AMAC). Portfolios 2-4 cover reputation quintiles. The top and bottom 2 portfolios (Q1A, Q1B, Q5A, and Q5B) divide the extreme quintiles in half. The returns presented in the table are averages over all formation periods. $R_{t}$ is the average return in year $t$ after formation, $t=1, \ldots, 5$. AR is the average annual return over five postformation years. $\mathrm{CR}_{5}$ is the compounded 5-year return assuming annual rebalancing. $M A R_{t}$ is the average market-adjusted return in year $t$ after formation, $t=1, \ldots, 5$, where the market performance is measured by a value weighted market index. AMAR is the average annual market-adjusted return over five postformation years. $\mathrm{CMAR}_{5}$ is the compounded 5-year market-adjusted return assuming annual rebalancing. $\mathrm{BHAR}_{\mathrm{t}}$ is the one year buy-and-hold abnormal return, adjusted for size and book-to-market effects, in year $t$ after formation, $t=1, \ldots, 5$. ABHAR is the average annual abnormal return over five postformation years. $\mathrm{CBHAR}_{5}$ is the compounded 5-year abnormal return assuming annual rebalancing.

\begin{tabular}{|c|c|c|c|c|c|c|c|}
\hline & \multicolumn{5}{|c|}{ Most-Admired } & \multicolumn{2}{|c|}{ Least-Admired } \\
\hline & Q1A & Q1B & Q2 & Q3 & Q4 & Q5A & Q5B \\
\hline \multicolumn{8}{|c|}{ Panel A: Raw Returns } \\
\hline $\mathrm{R}_{1}$ & 0.183 & 0.164 & 0.162 & 0.153 & 0.175 & 0.144 & 0.119 \\
\hline $\mathrm{R}_{2}$ & 0.202 & 0.162 & 0.166 & 0.173 & 0.164 & 0.159 & 0.143 \\
\hline $\mathrm{R}_{3}$ & 0.191 & 0.182 & 0.146 & 0.185 & 0.155 & 0.177 & 0.143 \\
\hline $\mathrm{R}_{4}$ & 0.158 & 0.134 & 0.153 & 0.122 & 0.131 & 0.169 & 0.137 \\
\hline $\mathrm{R}_{5}$ & 0.150 & 0.139 & 0.132 & 0.128 & 0.131 & 0.136 & 0.083 \\
\hline AR & 0.177 & 0.156 & 0.152 & 0.152 & 0.151 & 0.157 & 0.125 \\
\hline $\mathrm{CR}_{5}$ & 1.255 & 1.065 & 1.027 & 1.028 & 1.021 & 1.072 & 0.800 \\
\hline \multicolumn{8}{|c|}{ Panel B: Market-Adjusted Returns } \\
\hline $\mathrm{MAR}_{1}$ & 0.037 & 0.018 & 0.016 & 0.007 & 0.029 & -0.003 & -0.028 \\
\hline $\mathrm{MAR}_{2}$ & 0.048 & 0.009 & 0.012 & 0.019 & 0.011 & 0.007 & -0.011 \\
\hline $\mathrm{MAR}_{3}$ & 0.040 & 0.031 & -0.004 & 0.034 & 0.004 & 0.027 & -0.007 \\
\hline $\mathrm{MAR}_{4}$ & 0.029 & 0.004 & 0.023 & -0.007 & 0.002 & 0.040 & 0.006 \\
\hline $\mathrm{MAR}_{5}$ & 0.031 & 0.020 & 0.013 & 0.009 & 0.012 & 0.018 & -0.038 \\
\hline AMAR & 0.037 & 0.016 & 0.012 & 0.012 & 0.012 & 0.018 & -0.016 \\
\hline $\mathrm{CMAR}_{5}$ & 0.199 & 0.084 & 0.062 & 0.062 & 0.060 & 0.092 & -0.076 \\
\hline
\end{tabular}




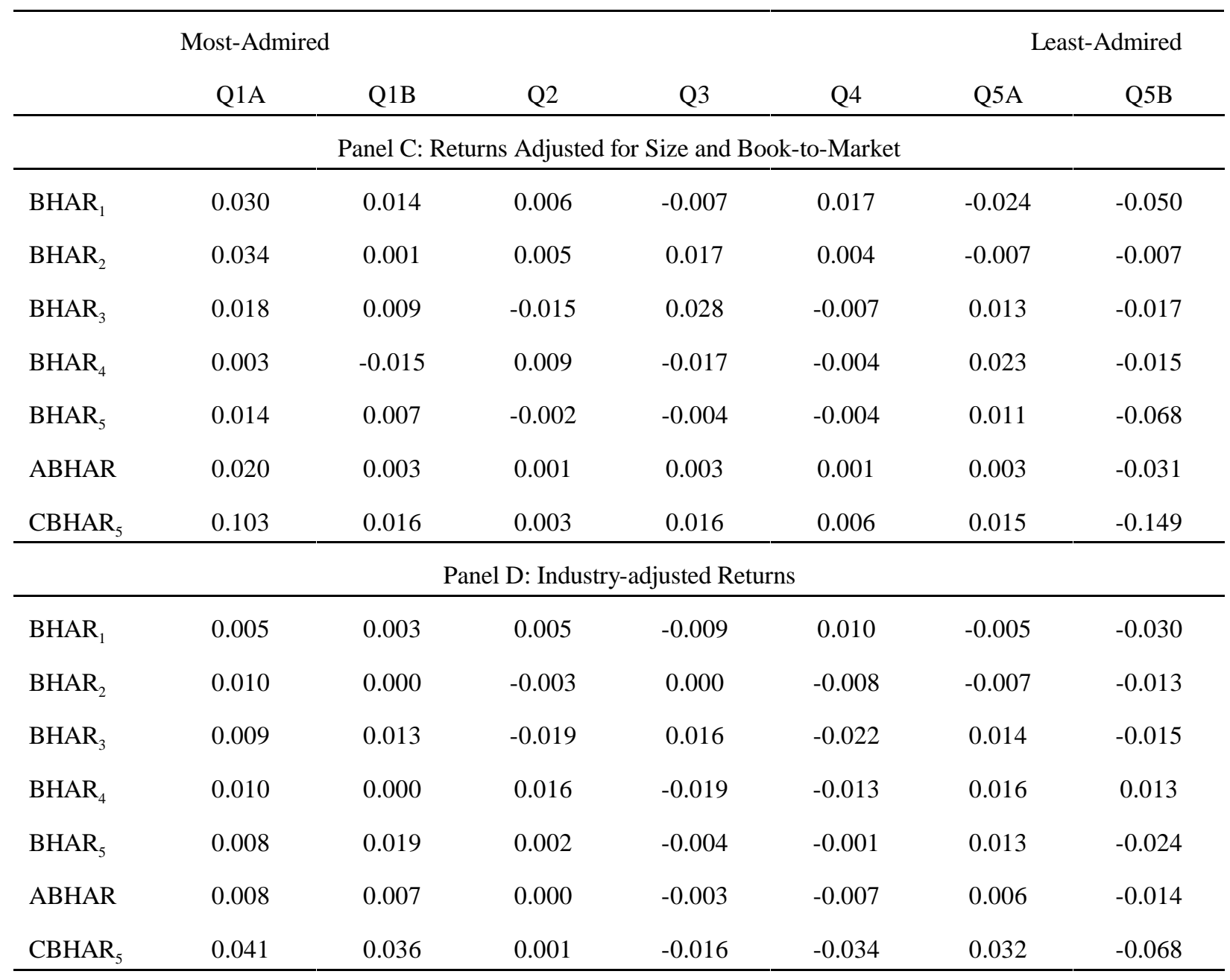




\section{Table III}

\section{Returns on Reputation Portfolios by Calendar Months and Quarters}

The reputation portfolios, based on overall reputation as ranked in the Fortune magazine annual survey of America's Most Admired Companies (AMAC), are formed each April after the survey appears and held for one year. Portfolios 2-4 cover reputation quintiles. The top and bottom 2 portfolios (Q1A, Q1B, Q5A, and Q5B) divide the extreme quintiles in half. The returns presented in the table are average returns over all formation periods. Panel A presents the returns by calendar month. Column 2 contains the returns from a strategy of buying the decile of the most admired firms (Q1A) and shorting the decile of the least admired firms (Q5B). Panel A also contains the average monthly returns, adjusted for size and book-to-market effects, and the percentage of positive returns in each calendar month. Panel B presents the quarterly returns adjusted for the CRSP value-weighted index for all seven portfolios.

\begin{tabular}{|c|c|c|c|c|c|c|}
\hline \multicolumn{7}{|c|}{ Panel A: Returns by Calendar Month } \\
\hline & $\begin{array}{c}\text { Return } \\
\text { Difference } \\
\text { Q1A - Q5B }\end{array}$ & $\begin{array}{l}\text { Proportion of } \\
\text { Positive } \\
\text { Returns }\end{array}$ & $\begin{array}{c}\text { Adjusted } \\
\text { Returns } \\
\text { Q1A }\end{array}$ & $\begin{array}{l}\text { Proportion of } \\
\text { Positive } \\
\text { Returns }\end{array}$ & $\begin{array}{c}\text { Adjusted } \\
\text { Returns } \\
\text { Q5B }\end{array}$ & $\begin{array}{l}\text { Proportion of } \\
\text { Positive } \\
\text { Returns }\end{array}$ \\
\hline Apr. & $\begin{array}{c}0.0133 \\
0.98\end{array}$ & 0.69 & $\begin{array}{c}0.0022 \\
0.66\end{array}$ & 0.54 & $\begin{array}{c}-0.0131 \\
(1.19)\end{array}$ & 0.31 \\
\hline May & $\begin{array}{c}0.0238 \\
3.10\end{array}$ & 0.77 & $\begin{array}{c}0.0046 \\
0.93\end{array}$ & 0.62 & $\begin{array}{c}-0.0163 \\
(2.47)\end{array}$ & 0.23 \\
\hline Jun. & $\begin{array}{c}0.0176 \\
1.71\end{array}$ & 0.69 & $\begin{array}{c}0.0071 \\
1.60\end{array}$ & 0.54 & $\begin{array}{c}-0.0098 \\
(1.01)\end{array}$ & 0.31 \\
\hline Jul. & $\begin{array}{c}-0.0113 \\
(0.88)\end{array}$ & 0.38 & $\begin{array}{c}0.0013 \\
0.33\end{array}$ & 0.62 & $\begin{array}{c}0.0065 \\
0.94\end{array}$ & 0.62 \\
\hline Aug. & $\begin{array}{c}0.0012 \\
0.10\end{array}$ & 0.54 & $\begin{array}{c}-0.0049 \\
(1.56)\end{array}$ & 0.38 & $\begin{array}{c}-0.0063 \\
(0.65)\end{array}$ & 0.31 \\
\hline Sep. & $\begin{array}{c}0.0046 \\
0.35\end{array}$ & 0.54 & $\begin{array}{c}-0.0050 \\
(1.22)\end{array}$ & 0.31 & $\begin{array}{c}-0.0114 \\
(1.04)\end{array}$ & 0.31 \\
\hline Oct & $\begin{array}{c}0.0513 \\
3.25\end{array}$ & 0.85 & $\begin{array}{c}0.0055 \\
1.14\end{array}$ & 0.62 & $\begin{array}{c}-0.0252 \\
(2.33)\end{array}$ & 0.23 \\
\hline Nov. & $\begin{array}{c}0.0153 \\
1.18\end{array}$ & 0.69 & $\begin{array}{c}0.0022 \\
0.55\end{array}$ & 0.38 & $\begin{array}{c}-0.0107 \\
(1.25)\end{array}$ & 0.38 \\
\hline Dec. & $\begin{array}{l}0.0236 \\
2.13\end{array}$ & 0.77 & $\begin{array}{c}0.0060 \\
1.79\end{array}$ & 0.69 & $\begin{array}{c}-0.0129 \\
(1.78)\end{array}$ & 0.15 \\
\hline Jan. & $\begin{array}{c}-0.0617 \\
(3.25)\end{array}$ & 0.15 & $\begin{array}{c}-0.0029 \\
(0.55)\end{array}$ & 0.46 & $\begin{array}{c}0.0391 \\
3.16\end{array}$ & 0.92 \\
\hline Feb. & $\begin{array}{c}-0.0229 \\
(1.24)\end{array}$ & 0.38 & $\begin{array}{c}0.0013 \\
0.40\end{array}$ & 0.38 & $\begin{array}{c}0.0095 \\
0.65\end{array}$ & 0.54 \\
\hline Mar. & $\begin{array}{c}-0.0125 \\
(1.20)\end{array}$ & 0.23 & $\begin{array}{c}0.0059 \\
1.43\end{array}$ & 0.62 & $\begin{array}{c}0.0144 \\
1.70\end{array}$ & 0.77 \\
\hline
\end{tabular}




\begin{tabular}{cccccccc}
\hline \multicolumn{7}{c}{ Panel B: Market-adjusted Returns by Quarter } \\
\hline & Most-Admired & & & \multicolumn{2}{c}{ Least-Admired } \\
Quarter & Q1A & Q1B & Q2 & Q3 & Q4 & Q5A & Q5B \\
\hline Apr. - Jun. & 0.010 & 0.005 & -0.003 & -0.016 & -0.006 & -0.003 & -0.045 \\
& 0.85 & 0.58 & -0.41 & -2.92 & -0.85 & -0.17 & -2.53 \\
Jul. - Sep. & -0.008 & -0.008 & -0.001 & 0.007 & -0003 & -0.026 & -0.001 \\
& -1.00 & -1.04 & -0.16 & 1.55 & -0.41 & -1.72 & -0.03 \\
Oct. - Dec. & 0.024 & 0.005 & 0.002 & -0.003 & -0.003 & -0.006 & -0.067 \\
& 3.65 & 0.75 & 0.33 & -0.55 & -0.32 & -0.36 & -2.69 \\
Jan. - Mar. & 0.004 & 0.013 & 0.008 & 0.016 & 0.033 & 0.037 & 0.111 \\
& 0.55 & 1.94 & 1.01 & 2.01 & 3.35 & 3.02 & 2.97 \\
\hline
\end{tabular}


Table IV

Year-by-Year Returns on Reputation Portfolios

The reputation portfolios, based on overall reputation as ranked in the Fortune magazine annual survey of America's Most Admired Companies (AMAC), are formed each April after the survey appears and held from 9 months up to 5 years. The second column in the table reports the differences in five-year returns between the decile portfolio of the most admired firms (Q1A) and the decile portfolio of the least admired firms (Q5B), for a holding period of 5 years. The rest of the columns report the returns adjusted for size and book-to-market effects using Barber, Lyon, and Tsai (1998) procedure, for holding periods of 9 month, 1 year, and 5 years. The reported p-values are based on Newey-West standard errors.

\begin{tabular}{|c|c|c|c|c|c|c|c|}
\hline \multirow[b]{3}{*}{ Year } & \multirow{3}{*}{$\begin{array}{c}\text { Difference in } \\
\text { Raw Returns }\end{array}$} & \multicolumn{6}{|c|}{ Returns Adjusted for Size and Book-to-Market } \\
\hline & & \multicolumn{3}{|c|}{ Most-Admired (Q1A) } & \multicolumn{3}{|c|}{ Least-Admired (Q5B) } \\
\hline & & 9-month & 1-year & 5-year & 9-month & 1 -year & 5-year \\
\hline 1983 & 0.133 & -0.096 & -0.085 & -0.060 & 0.082 & 0.060 & -0.182 \\
\hline 1984 & 1.104 & 0.046 & 0.067 & 0.061 & -0.202 & -0.180 & -0.387 \\
\hline 1985 & 0.876 & 0.011 & 0.062 & 0.095 & -0.112 & -0.085 & -0.256 \\
\hline 1986 & 0.808 & 0.071 & 0.096 & 0.079 & -0.097 & -0.098 & -0.291 \\
\hline 1987 & 0.933 & 0.008 & -0.019 & 0.172 & -0.056 & -0.045 & -0.467 \\
\hline 1988 & 0.881 & -0.012 & 0.017 & 0.103 & -0.053 & 0.024 & -0.349 \\
\hline 1989 & 0.939 & 0.057 & 0.036 & 0.103 & -0.218 & -0.224 & -0.442 \\
\hline 1990 & 0.279 & 0.111 & 0.169 & 0.153 & -0.235 & -0.151 & -0.031 \\
\hline 1991 & -1.120 & 0.040 & 0.039 & 0.137 & -0.266 & -0.066 & 0.356 \\
\hline 1992 & & -0.003 & -0.010 & & -0.100 & 0.032 & \\
\hline 1993 & & -0.034 & -0.038 & & -0.062 & -0.124 & \\
\hline 1994 & & 0.020 & 0.008 & & 0.065 & 0.200 & \\
\hline 1995 & & 0.045 & 0.046 & & -0.043 & 0.003 & \\
\hline Mean & 0.537 & 0.020 & 0.030 & 0.094 & -0.100 & -0.050 & -0.228 \\
\hline p-value & 0.058 & 0.182 & 0.119 & 0.008 & 0.006 & 0.138 & 0.033 \\
\hline
\end{tabular}


Table V

\section{Returns on Reputation Portfolios in Months with Best and Worst Market Returns}

The reputation portfolios, based on overall reputation as ranked in the Fortune magazine annual survey of America's Most Admired Companies (AMAC), are formed each April after the survey appears and held for one year. Portfolios 2-4 cover reputation quintiles. The top and bottom 2 portfolios (Q1A, Q1B, Q5A, and Q5B) divide the extreme quintiles in half. All the moth in the sample are ranked based on the performance of an equally weighted market index during the month into 10 worst months $\left(\mathrm{W}_{10}\right)$, the 41 negative moths other than the 10 worst $\left(\mathrm{N}_{41}\right)$, the 95 positive other than the 10 best $\left(\mathrm{P}_{95}\right)$, and the 10 best months $\left(\mathrm{B}_{10}\right)$, This table reports the average monthly buy-and-hold return on the reputation portfolios over the $\mathrm{B}_{10}, \mathrm{P}_{95}, \mathrm{~N}_{41}$, and $\mathrm{W}_{10}$ months.

\begin{tabular}{lcccc}
\hline Portfolio & $\mathrm{W}_{10}$ & $\mathrm{~N}_{41}$ & $\mathrm{P}_{95}$ & $\mathrm{~B}_{10}$ \\
\hline Q1A Most Admired & -0.082 & -0.017 & 0.028 & 0.103 \\
Q1B & -0.088 & -0.022 & 0.030 & 0.099 \\
Q2 & -0.088 & -0.021 & 0.029 & 0.096 \\
Q3 & -0.080 & -0.019 & 0.027 & 0.097 \\
Q4 & -0.084 & -0.018 & 0.030 & 0.087 \\
Q5A & -0.098 & -0.025 & 0.031 & 0.095 \\
Q5B Least Admired & -0.100 & -0.026 & 0.029 & 0.096 \\
Q1A - Q5B & 0.018 & 0.009 & -0.001 & 0.007 \\
\hline
\end{tabular}




\section{Table VI}

\section{Industry vs. Firm-Specific Returns to Reputation}

The reputation portfolios, based on overall reputation as ranked in the Fortune magazine annual survey of America's Most Admired Companies (AMAC), are formed each April after the survey appears and held from one to five years. Q1A is an equally weighted portfolio of the most admired decile, and Q1B is an equally weighted portfolio of the least admired decile. This table reports the decomposition of incremental annual returns, from the first to the fifth year after formation, into an industry and a firm-specific component. Each of the sample firms in the two extreme reputation portfolios is matched with an industry reference portfolio. The industry reference portfolio consists of the firms that are in the same Fortune industry as the sample firm, excluding the sample firm itself. The industry return is then defined as an equally weighted return on the set of industry reference portfolios. Firm-specific return is defined as the difference between the return on an equally weighted portfolio of sample firms and the corresponding average industry return. The table reports the averages across all formation periods.

\begin{tabular}{|c|c|c|c|c|c|c|c|c|c|c|}
\hline & \multicolumn{5}{|c|}{ Most-Admired (Q1A) } & \multicolumn{5}{|c|}{ Least-Admired (Q5B) } \\
\hline & $\begin{array}{l}\text { Industry } \\
\text { Return }\end{array}$ & + & $\begin{array}{c}\text { Firm } \\
\text { Specific } \\
\text { Return }\end{array}$ & $=$ & $\begin{array}{l}\text { Total } \\
\text { Return }\end{array}$ & $\begin{array}{l}\text { Industry } \\
\text { Return }\end{array}$ & + & $\begin{array}{c}\text { Firm } \\
\text { Specific } \\
\text { Return }\end{array}$ & $=$ & $\begin{array}{l}\text { Total } \\
\text { Return }\end{array}$ \\
\hline $\mathrm{R}_{1}$ & 0.175 & & 0.005 & & 0.180 & 0.151 & & -0.030 & & 0.121 \\
\hline $\mathrm{R}_{2}$ & 0.193 & & 0.010 & & 0.203 & 0.152 & & -0.013 & & 0.139 \\
\hline $\mathrm{R}_{3}$ & 0.181 & & 0.009 & & 0.190 & 0.155 & & -0.015 & & 0.139 \\
\hline $\mathrm{R}_{4}$ & 0.148 & & 0.010 & & 0.158 & 0.127 & & 0.013 & & 0.140 \\
\hline $\mathrm{R}_{5}$ & 0.141 & & 0.008 & & 0.149 & 0.110 & & -0.024 & & 0.086 \\
\hline $\mathrm{AR}$ & 0.168 & & 0.008 & & 0.176 & 0.139 & & -0.014 & & 0.125 \\
\hline
\end{tabular}




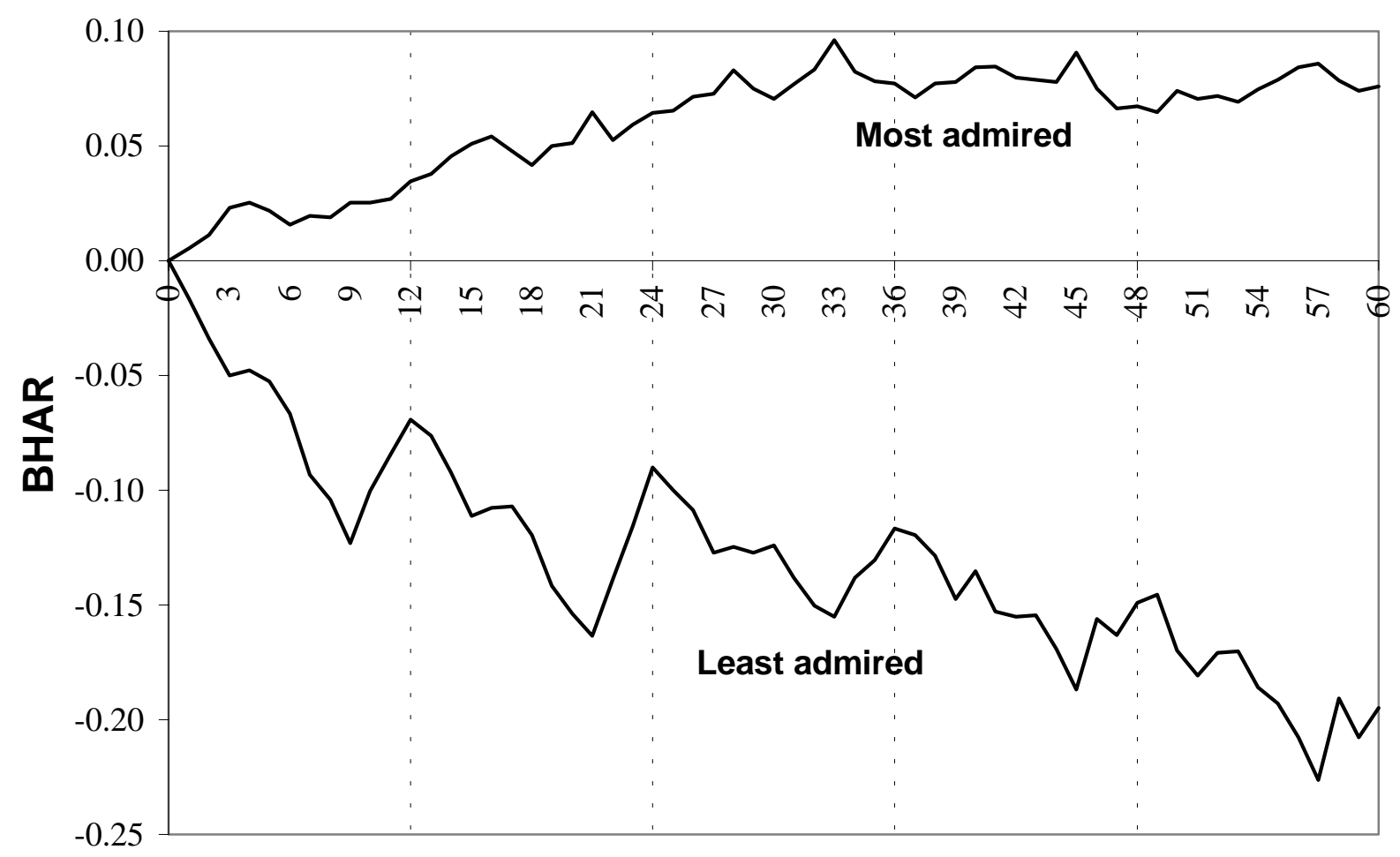

Months After Portfolio Formation

Figure 1. Five year buy-and-hold abnormal returns: Most admired versus least admired firms. Reputation portfolios, based on overall reputation as ranked in the Fortune magazine annual survey of America's Most Admired Companies (AMAC), are formed each April after the survey appears and held for five years. The portfolios are rebalanced into equally weighted portfolios at the start of April of each year. The numbers presented are the buy-and hold abnormal returns (BHAR) for the decile of the most admired and the decile of the least admired firms. BHAR are calculated based on the returns adjusted for size and book-to-market effects using Barber, Lyon, and Tsai (1998) procedure. 


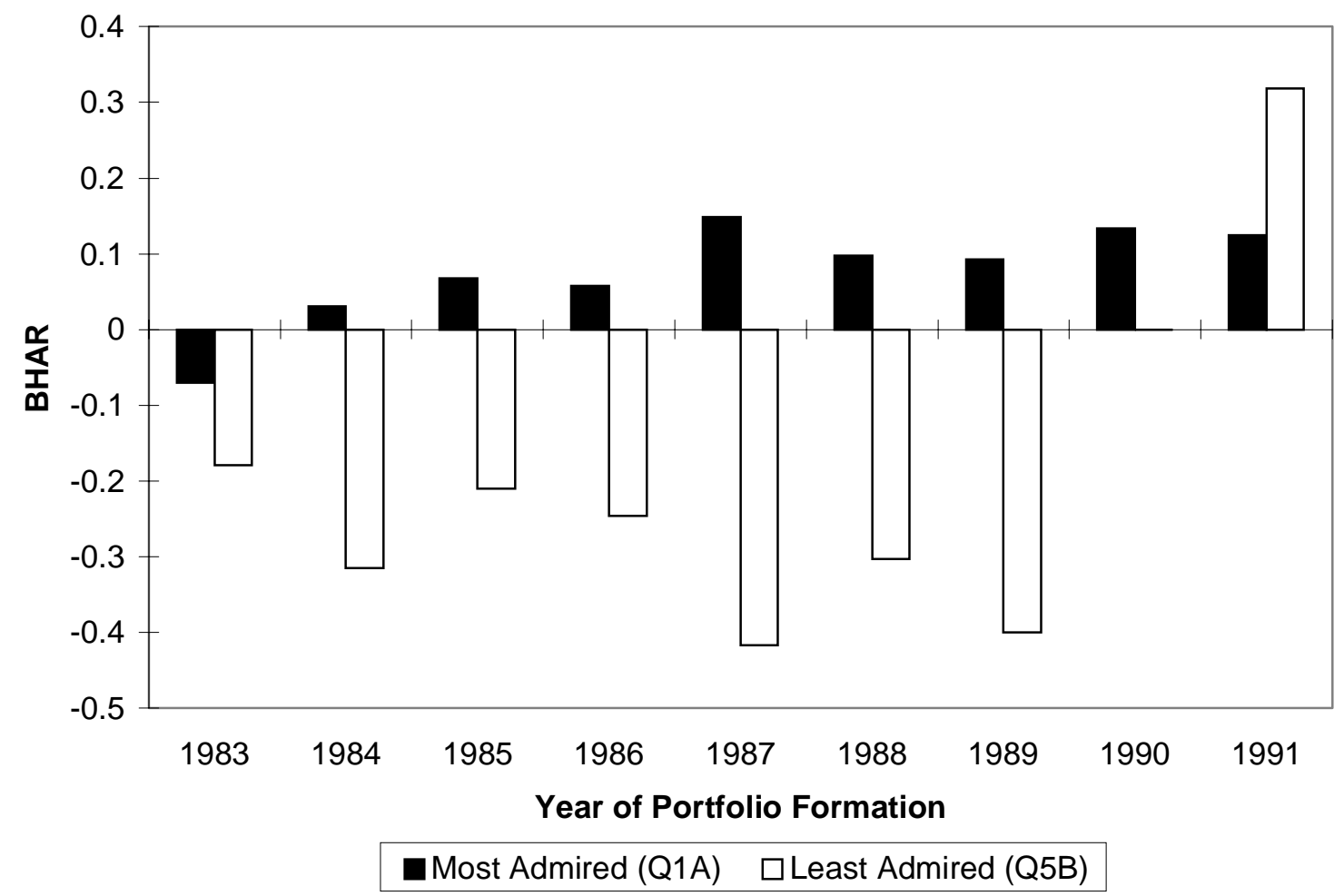

Figure 2. Year-by-year returns to the decile portfolios of most and least admired firms. Reputation portfolios, based on overall reputation as ranked in the Fortune magazine annual survey of America's Most Admired Companies (AMAC), are formed each April after the survey appears and held for five year. We start by computing an annual buyand-hold abnormal returns on an equally weighted decile portfolio of the most and the least admired firms, and the return on the corresponding reference portfolios for each of the five years after the formation. The reference portfolios are constructed based on Barber, Lyon, and Tsai (1998) procedure and match the sample firms on size and book-to-market ratio. If a particular firm (either in portfolio Q1A, Q5B or in any of the reference portfolios) is delisted from the CRSP during a particular year, its returns are replaced by a zero until the end of the current annual holding period. At the start of the next annual holding period, the delisted firms are dropped and the remaining firms are rebalanced into an equally weighted portfolio. The numbers in the chart represent a compounded five-year return on the decile portfolios of the most admired (Q1A) and least admired firms (Q5B) minus the compounded five-year return on the corresponding reference portfolios. 